\title{
THE INTERNATIONAL FINANCIAL CRISIS OF 2008-2009 FACING THE CONGOLESE ECONOMY
}

PhD. Marcel Kamba-Kibatshi ${ }^{1 *}$

*lDepartment of Economics, Institute of Sociology, Faculty of Historical and Social Sciences, University of Cardinal Stephane Wyszynski in Warsaw

\section{*Corresponding Author: -}

\begin{abstract}
: -
This article describes the international financial crisis of 2008-2009 facing the Congolese economy. The international financial crisis has created serious dangers for the Congolese economy in terms of job losses and declining quality of life. This article describes the global economic crisis and its direct impact in the Democratic Republic of Congo. The economic and financial crisis is global and it also affects the most vulnerable countries such as African countries. This is true since it is generally accepted that the economic situation has an influence on the social situation. Indeed, although the crisis was triggered by events in the US real estate market, it has spread to all regions of the world, with disastrous consequences for trade, growth and economic growth. global investments. In the Democratic Republic of Congo, the rapidly advancing global financial crisis is taking over businesses, mines, jobs, income and livelihoods. Time is running out and decisive action cannot wait.
\end{abstract}

Keywords: financial crisis; global financial crisis; Central Bank of Congo Code JEL : E5, E32, E44, F32, 


\section{INTRODUCTION}

\section{Problematic}

For some time, the international financial crisis has been in the news. Not a day goes by without this crisis being mentioned by the national and international media. Today we say that the financial crisis has really reached the doors of the Democratic Republic of Congo. As proof, several companies, especially mining and forestry have experienced a decline in all their stock market shares. Since independence, the Democratic Republic of Congo has experienced permanent instability in the economy, which has seriously affected the fundamental equilibrium of the economy, leading to the collapse of the value of the national currency. Located in the heart of Africa, the Democratic Republic of Congo has experienced for several decades an economic crisis whose exit route remains problematic until today. Recall some economic facts that have further accentuated the economic crisis of the country include, among many others: Zairianization (around 1973). The looting of 1990, 1991 and 1993. The 1996 and 1998 liberation wars in the east of the country and the bad governance that continues to characterize the country. These events and many others caused the collapse of the production tool, resulting in the collapse of the national economy. Our study concerns the examination of the international financial crisis that began in the USA on September 15, 2008 and spread quickly to the rest of the world, we want to understand the consequences of this crisis on the economy of the Democratic Republic of Congo, which is already fragile and in crisis, the focus on the effects of the crisis will be on the international trade sector: exports of mining and forestry products, imports of industrial and food products. The essence of our problem is the following questions:

- Will this crisis last a long time? Will it be solved by technical adjustments (lowering of credit rates, injection of funds)?

- Can the call to the state cover today's losses and guarantee the profit of tomorrow? will it change anything?

- Has the permanent instability of the economy of the Democratic Republic of Congo, already in crisis, been exacerbated by the contagion of the international crisis, particularly in the commodity export sector and the imports of goods? industrial and food products. ?

\section{Hypothesis of the study}

The hypothesis of our study is as follows:

The Democratic Republic of Congo has undoubtedly been shaken by the international financial crisis, particularly in the commodity export sector and imports of industrial and food products.

\section{Research methods and techniques \\ 3.1. Methods}

They constitute a rational and scientific path in the search for explanations for the problems that we pose for this work. The different methods used in this work are:

\subsubsection{The deductive method}

This method allows the researcher to provide explanations from the theory of economic history concerning economic crises, in order to situate the international crisis that is the object of our work.

\subsubsection{Inductive method}

It allows the researcher to assess the financial crisis from the data obtained on the crisis: socalled "subprime" loans that are risky loans granted to a poor clientele, this market has largely developed in the US from 2001.

\subsection{Techniques}

\subsubsection{Documentary technique:}

It allowed us to have information by consulting books, reports, journals, memoirs, websites and other documents related to our subject

\subsubsection{Interview technique:}

It helped us to gather necessary information by contacting some officials of the Ministry of the Economy, and the competent people in economic knowledge: the scientific community.

\section{Interest of the subject}

In view of the subject that we develop in our work it is necessary for us to explain in a precise way the fundamental reasons which are at the base of our choice:

- The international financial crisis has affected the economy of our country, the daily life of the Congolese population becomes a headache;

- The crisis has exacerbated our already difficult living conditions; $\square$ The national economy is struggling today.

\section{Spatio-temporal delimitation}

For reasons of precision and clarity, our reflection is delimited in space and time.

- In space our field of investigation is the Democratic Republic of Congo;

- In time we will deal with data related to the international financial crisis of 20082009. 


\section{Division of the work}

Ignoring the introduction and conclusion our study has three parts.

- first, let's talk about the history of economic crises in the Word;

- Second, the root causes of the 2008-2009 international financial crisis;

- and in the end the Congolese economy in the face of the international financial crisis of 2008-2009

\section{Part 1. History of the world's economic crises}

\subsection{Background of the crisis phenomenon in the capitalist economy}

The engine of the capitalist economy is individual profit, which has no limit. This economy is based on the principle of free competition and individual initiative. It is based on the creation of the company whose object is the enrichment of its founder, and on the use of a salaried workforce. The nineteenth century was the golden age of capitalism, still characterized by industrialization, the use of credit, mass production, crises. Capitalist crises are inevitable because it is the pursuit of profit and of general interest that drives economic development. When purchasing power decreases, the consumer buys less, industries are often in difficulty and need banks to maintain their activities. If the bad persists, the factories close, the unemployment spreads and decreases the consumption, the stock accumulates, the price collapses, the weakest companies disappear, dragging with them the banks too engaged. But other companies resist, absorbing even their competitors: the concentration increases. When consumption resumes, commercial and banking industrial activities are experiencing a new boom, businesses are fewer and more powerful than before the crisis. The intervention of the State makes less serious the crisis, it becomes the recession, being able nevertheless lasting more than one year, it is the case of the recession in the US of 1957 - 1958[Cartanapis André, 2009, pp. 101-103].

\subsubsection{History of economic crises}

An economic crisis by definition is a brutal deterioration of the economic situation and that of its prospects. Its sectoral temporal and geographical scope can range from one sector, from one region for a short period to the entire world economy. for several years. We will then see economic slowdown or, more serious economic recession. Such a crisis has repercussions as Gottfried Haberler says[Amesila, 2009, pp. 62-63] it is the moment of turning of an economic cycle. In Marxist theory, if the crisis is understood as a means leading to the fall of capitalism, crises in capitalist economy are interpreted as the means by which the country is reorganized. Usually, in the English language, the word economic crisis is understood in the Marxist sense. In this sense, it is preferred to the more economic terms: depression or recession. So the 1929 crisis is called Great Depression or the economic crisis of 2008 - 2009 is called Great Recessions. In French, the term crisis usually includes the idea, close to the Marxist, the economic crisis is sometimes seen as a phenomenon that ends with the adoption of a new economic structure[Bendera Omar, 2010, pp. 36-37] . The world has experienced several economic crises that we can not identify in this work. We will limit ourselves to the economic crisis of 1929 and Asia of 1997 before dedicating our analysis on the international financial crisis of $2008-2009$.

\section{The economic crisis of 1929 (Great Depression)}

This crisis is in the period of world history that goes from the crash of 1929 in the United States to the second world war. It is the most important economic depression of the 20th century, accompanied by high inflation and an explosion of unemployment. After the crash of October 29, 1929[Esico Fatuma, 2012, pp. 52-53 ], in the United States, one of the main problems was that with deflation, the same amount of money allowed to acquire more and more goods as and when falling prices. In these circumstances, economic agents have an individual interest in:

- wait as much as possible before buying: consumption drops;

- keep their goods in the form of money rather than productive assets: the investment falls.

The stock market and banking crisis follows:

The population is entering a destructive vicious circle, which will last several years. The fall is also reflected in stock prices: the Dow Jones index loses almost 90\% and enters its highest in 1929 and its lowest in 1932 in the bursting of the speculative bubble, too many investment plans are proved insolvent, fraudulent, the stock market crisis degenerates very quickly into a banking crisis. Caught between the collapse of value and their asset sometimes too much engaged in questionable business, but even reputable solid companies are slaughtered. The defaults of repayment of their borrowers, and the reduction of their credit activities, of banks go bankrupt and finally in 1932 the banking system melts.

\subsubsection{The causes of the economic crisis of 1929}

The economic reflection a posteriori focused on the one hand on the immediate causes of the crisis and on the other hand on reasons for the transformation and recession into depression. But the innumerable writings on the crisis of 1929 did not allow drawing a generally accepted explanation of its occurrence. The works devoted to it are most often descriptive and possibly normative.

Rarely explanatory, what is simply necessary to know that in October 1929 an economic crisis falls abruptly on the world. She explains:

- by the end of reconstructions: most countries have repaired the damage of wars and very often have managed to modernize their industries to increase their agricultural production;

- by the instability of the currencies: it starts in the United States because the production was the most advanced, the Americans practiced on a large scale the sale on credit: on the simple payment of a deposit, one can buy anything. The balance is paid by monthly installments. 
In 1977 the speculations of the big financial institutions destabilized the currencies of the developing countries in Asia from where a regional economic crisis called Asian crisis.

\section{A. Asian crisis and his genesis}

This crisis marks the temporary end of the economic miracle of the last four decades in East and Southeast Asia, the most severely affected countries are:

- Thailand;

- Indonesia;

- South Korea.

These countries have dragged the whole region into a phase of slowing growth, even economic recession, and the rapid devaluation of Thailand's national currency in July 1997 marked the beginning of what is commonly known as the crisis. Asian. A regional and financial economic crisis that brought several East Asian countries into recession the following summer. The crisis had led to an economic upheaval on the international markets, the repercussions of which would be worse than those of the great crisis of 1929. Michel chossudovscky asserts. Since the 1980s, national economies have collapsed as a result of macroeconomic reforms undertaken under the auspices of Bretton Wood at the IMF. Still, Chossudovsky reports that economic crises since the middle of 1977 are due to speculation by major financial institutions and banks that destabilize primary currencies (of developing countries) by placing floating capital there to say short-term capital quickly passing from one place to another.

\section{B. The origins of the crisis [MISHKIN, 2007, p.71]}

The main reasons given are the internal causes. The excessive volume of private borrowing from abroad, in fact, there have been strong fluctuations in the international capital markets and the inadequate policy adopted by the IMF (International Monetary Fund) in the face of this situation, it must be emphasized that the excessive volume of private borrowing abroad combined with the weakness or even lack of banking supervision and the surveillance of currencies linked to the US dollar (overvaluation of the currency) by fixed parities or low margins of fluctuation . The crisis that erupted in the mid-1977s has taken on an unexpected magnitude and can no longer be contained by a few corrective measures in economic policies.

This is a major structural crisis that started.

\section{Asian dragons and Asian tigers [World Bank Report, 2009, p. 205]}

The economic situation of these countries in the 1950s is hardly flourishing except for Japan; the next decade gradually saw the "dragons" develop, then the "tigers" from the 1970s. The recent strikes as well as economic difficulties come to undermine one of the favorite arguments.

\section{Amplification of the crisis at the end of 1977}

After the tigers, the crisis spreads to the dragons: the Won loses 50\% against the dollar in November. At the end of 1997 , twelve emerging countries were affected (tigers, dragons, brazil, argentina, India). The Tigers:

- Thailand;

- Indonesia;

- Malaysia;

- The dragons;

- South Korea;

- Tajwan;

- Hong Kong;

- Singapore.

Financial crisis of 2008-2009 (Great recession) [World Bank Report, 2012, p. 205]. Called often in the English-speaking Great Recession world (recessional rigidity) is a recession in which most of the industrialized countries entered the world following the crash of the Autonomous 2008, second phase of the financial crisis of 2007 - 2010. The United States was the first to go into recession in December 2007, followed by several European countries in 2008 and the euro area as a whole. France enters completely into recession only in 2009. This global economic crisis is considered the worst since the Great Depression of the years $1929-1930$ by a sharp rise in prices of oil and agricultural products.

\subsubsection{History of the international financial crisis (2007-2009)}

The beginnings of the crisis date back to the early 2000s. The aggressive credit policy in the United States and the prudential by-pass by banks worsened the real estate crisis to make it more general securitization spread the crisis worldwide. The world will change after this international financial crisis, it is the claims of many internationalist economists without giving a clear outline to what will be the future economic and financial world. More than a year after its engagement in the United States, in summer 2007, the crisis is wreaking havoc. Global stock markets are still very volatile, large banks deposit balance sheets one after the other. It is not yet time to reflect on the root causes of this most important financial disaster in the history of the crisis ". The second phase of the financial crisis begins in the week of February 14, 2008 when several US financial institutions default, and are either saved in extremis by the US Federal Reserve (EDF), the insurance company AIG by for example, either bought by competitors in better situations or put into 
liquidation [NKERE, 2009, p. 97]. The crisis affects all the countries in the world, particularly in Europe, where several financial institutions are facing serious difficulties and are being saved by the intervention of European central banks and states in the euro zone.

\section{Part 2. The foundation of the 2008-2009 financial crisis 2.1. Fundamental Cause of the 2008-2009 Financial Crisis}

The root cause of the crisis comes from the extraordinary US monetary policy in recent years. However, this is clearly evident by public authorities and not by the market, this is how the Fed went from an interest rate of $6.5 \%$ in 2000 to a rate of $1.75 \%$ at the end of 2001 and $1 \%$ in 2003, there was a slow recovery from 2004 to $4.5 \%$ in 2006 during the entire period of low interest rates and easy credit. The world has been swamped with liquidity to take advantage of this wonderful opportunity for easy profit. Financial institutions have provided loans to less and less successful borrowers. As the subprime shows when one has returned to more normal interest rates [Philippe Hugon, 2009, pp. 231-232]. The excesses of the past have come to light; it is the bursting of the "financial ball".

The negative consequences of this American monetary policy have been aggravated by several phenomena. First of all, the sense of responsibility for risk is blunted because it implicitly admitted that public institutions could not produce large bankruptcies in the event of difficulties (which is partly confirmed by the current behavior of the authorities. American). In particular, the two major purveyors of "subprime" credit Fannie and Freddie Mae initially created by the US state enjoyed privileged state guarantees that led them to take very excessive risk, the financial regulation itself is the source. The perverse effect of this is the obligation imposed on banks by the Basel II agreement to maintain a capital ratio of $8 \%$ of their assets. Faced with the tremendous gains opportunities created by the Fed's low interest rate policy. Banks wanted to maximize their credit, while maintaining the ratio imposed by regulation.

In this situation, they have sought to circumvent the regulation as is always the case by getting rid of some of their outstanding amounts to other organizations such as investment funds and SIV (structured investment vehicles) part of the credits granted banks have disappeared from their balance sheets. Enabling them to increase lending in apparent compliance with the regulations. Admittedly, it may be considered desirable that own funds be "sufficient" in relation to the loaned funds. In the nineteenth century. Banks' own funds usually accounted for $60-80 \%$ of their balance sheets: bankers lent funds that belonged to their shareholders as well as to bank customers. The bankers were then true capitalists, that is to say, owners of capital and as such they were responsible.

In our time, it has been thought possible to base economic development on credit and not on equity, moreover, a large part comes from a creation ex nihilo namely expansionary monetary policy and not from voluntary savings. At the same time, the withering away of capitalism itself very often resulting from state interventionism has meant that the big banks are no longer run by capitalists, owners of capital, but by households that do not support the shareholder risk, and are tempted to maximize short-term profits.

\subsection{Role and mission of the banks [World Bank Report, 2010, pp. 72-73].}

The banks are financial institutions that accept deposits and make loans. Included are banks, commercial banks, mortgage companies and savings banks. Banks are the financial intermediaries with whom an individual is most often in contact. A person in need of a loan to buy a house, a car ... he usually gets it from a bank branch in rich countries. Nearly all of the population now has at least one bank account, and most people keep some of their financial wealth in the banks in the form of bank accounts. Banks are the most important financial intermediaries, they deserve the greatest attention but they are not the only important financial institutions, indeed, like financial companies, there are financial companies.

The general presentation of central banks shows that today almost all countries in the world have their central banks. They perform the same great functions, but there are important differences between these institutions which result from the monetary and political history, in fact, in particular, their degree of autonomy is variable. Two models of central banks oppose:

the bank under guardianship:

- Placed under the direct authority of the State;

- The independent central bank that receives no instructions from the government.

The missions of a modern central bank show that parfors sometimes attributed to the French economist LEON AUCHER the invention of the term "central bank" in the modern economy, the bank is generally defined by its functions. For Denise Flouzat $^{1}$ "the central bank" is defined as an institution that is at the center of payment systems to ensure the settlement and control, the expansion of the money supply, it is the institution considered as suitable to preserve confidence in the currency of the country. For Michel Albert ${ }^{2}$ a central bank is the public autonomy charged:

a) To control the financing of the economy by ensuring the issue of banknotes and granting credits to commercial banks as part of monetary policy;

b) To monitor and manage the "system" of payments related in particular to the clearing of checks and interbank transfers;

\footnotetext{
${ }^{1}$ Realization of the Year of the Financial Professions is ensured by an editorial committee led by Denise Flouzat and Pierre-Henri Cassou, accompanied by the editorial secretary Matthieu Carteret. The journal follows the same mission as the Center des Professions Financières which is [...]

${ }^{2}$ Elected on March 28, 1994 at the Academy of Moral and Political Sciences in the section Political Economy, Statistics and Finance, in the chair of Henri Guitton, he was president of the Academy in 2004. In economics he is the author of two famous theorems. the theorem says of the specialized worker or O.S. : "Any company in a high-standard country, and in the manufacturing sector, employing a large share of lowskilled labor, is destined for bankruptcy or relocation. His second theorem states: "employment is linked to economic growth, growth is linked to the state of our foreign trade, and the balance of our foreign trade is linked to the state of our apparatus. productive. "
} 
c) And in some countries to monitor the soundness of the banking and financial system.

Both definitions focus on a tripology of the function of the central bank.

\subsubsection{Role of the banks in the crisis [World Bank Report, 2010, pp. 72-73].}

Banks are often given a central role in triggering and exacerbating the crisis. It is therefore interesting to try to understand what has been and is today the responsibility of banks. The current situation does not show a major responsibility of the banks, contrary to what is often advanced: the decline in credit to households comes from household behavior: the increase in risk premiums on bank loans to companies that contribute to the braking of these credits and the normal correction of an anomaly and moreover does not have much effect on growth. The behavior of banks, before the crisis can be criticized, however, if one pays attention to the heterogeneity of the situations of the banking systems between the different countries: what is true to the. United States is often not in the euro area. This is sometimes forgotten. Before the crisis the banks in a very different way from one country to another, have:

- Badly priced risk, which they correct today;

- Overly developed their very risky activities (proprietary trading): hence the losses;

- Loaned (in the United States, United Kingdom) on the basis of the wealth and not the income of the borrower;

- Significantly increased the size of their balance sheet and indebtedness;

- Transformed risky credits into seemingly risk free (securitized) assets to sell to investors. The degree of risk having appeared later.

The responsibility of the banks before the crisis and today[Nosakwe , 2009, pp. 42-43] affirms that it is quite frequent to attribute to the banks on the one hand the responsibility of the crisis, on the other hand its aggravation today by the rationing of the credit. Analyzing the real responsibility of the banks is important, on the one hand to understand the sequence that led to the crisis and know what to reform and regulate on the other hand to take today the right measures, if the braking of the demand is not due to that of the bank credit, it is useless to persist to make the latter leave again. The behavior of the banks before the crisis[Guy Longueville and François , 2008, pp. 73-74] affirms that the first point that we want to notice is the following one: it is difficult to make an overall analysis of the behavior of the banks as it was different from one country to another in this which concerns the practice of credit distribution linked to the value of housing in the United States, the United Kingdom or the euro zone. While the role of stock market intermediaries[Amesila, 2009 , p. 71]confirms the uncertainties on the direct and indirect commitments of financial institutions in terms of credit risk but also the fear of a general slowdown in the activities of corporate and investment banking, very profitable and engine of growth in previous years, ended up causing a real crisis of confidence.

Having little precedent between banks. These have seen their main source of refinancing dry up. The interbank market and the ABCP (Aser backed commercial paper) issue. In the interbank market, where banks in a situation of surplus capital lend to those who lack them, distrust between banks themselves has led to a surge in the interbank rate. Moreover, in previous years, banks had put in place, called structured investment vehicles (SIVs), which issued low-rate commercial paper (Aser-backed commercial paper) sold to investors. the high funds were then lent in the long run at higher rates which allowed for a large margin of interest, only the short-term loans had to be renewed regularly (every three months). However, once the crisis of confidence in the banks began, investors settled and stopped funding the ABCP, forcing the banks to finance them themselves.

The banking liquidity crisis has led the European Central Banks (ECB) and the Federal Reserve (US) in the first place, to carry out massive liquidity infections in the interbank market in order to allow refinancing institutions their activity. and to avoid triggering a systematic crisis (crisis of the whole system). The first intervention took place on 09 August 2007, when the ECB infected 94.8 billion [Philippe Hugon, 2009, pp. 231-232] of euros that were missing from the market, this is the largest single-day provision of funds by the ECB , exceeding the loan of 6903 billion euro made after the attacks of 11 September 2001. According to the financial system of any country, banks traditionally finance themselves by borrowing on the money market at three-month maturities, the interest rate at which they borrow (in continental Europe it is the Eurobor 3 months) is usually 15 to 20 basis points higher ( 0.15 to $0.20 \%$, in plain language) than the central bank rate, which is considered the risk-free rate, the difference between the rate at which banks borrow and the key rate is called risk premium or (spreod) in English and is calculated by Ted index for the US case. From the crisis of confidence of August 2007 when the Eurobor rate has soared, reaching 4.95\% in December 2007, the key rate was 4\% (2007) and in normal times they would have borrowed at $4.20 \%$ in October 2008, the Ted rate has even reached the historical level of 4\% difference while it was $0.5 \%$ on average from 2004-2009. The sharp rise, has from August 2007 shortterm rates to which refinancing. Banks pose a real risk to their financial equilibrium [Central

Bank of Congo Report, 2009, pp. 41-42] : "Soaring bank refinancing market rates (Eonia and Eurodor) have become higher than long-term risk-free loans rates, an untenable situation for financial institutions".

Written on September 15th the specialized newspaper "invest". Indeed, some banks are borrowing at high rates to refinance previously granted credits at lower rates. The liquidity crisis is reinforced by the asymmetry of information between banks, which are therefore reluctant to lend to each other. We noticed during our study that stock market intermediaries have the following obligations that are recognized by law, including:

- financial advice;

- At the financial start;

- Financial management of the portfolio;

- Portfolio management or collective investment scheme in transferable securities;

- the investment of securities and financial products; 
- A guarantee of good issue for public and private companies;

- At the counterpart;

- market making;

- Share sharing.

The responsibility of the intermediaries in their missions [World Bank Report, 2009, p.39] show that the intermediaries on the stock exchange must present the sufficient guarantees with regard to: $\square$ Their organization;

- Their technical and financial means;

- The respectability and experience of their leaders;

- Their provision to ensure the safety of their clients' interests;

- Stock market intermediaries are approved by the Financial Market Council;

- Exchange Traders are responsible to their customers for the delivery and payment of what they sell and buy on the market;

- Intermediaries and personnel under their authority are bound by professional secrecy, they must act with loyalty and impartiality by ensuring the primacy of their customers over their own interests.

\section{Part 3. The Congolese economy in the face of the international financial crisis}

\subsection{At the macroeconomic level}

Already affected by the occupation of some of its mining areas by the various rebel troops, the Congolese economy was not spared by the international financial crisis that has already turned into an economic crisis. The decline in economic growth of the Democratic Republic of Congo's main partners will result in the decline of their imports (which constitute our exports), and of their direct and portfolio investments. It follows, The accentuation of the slowdown in economic growth of the Democratic Republic of Congo. The macroeconomic impact shows that in relation to the financial crisis, the Congolese financial sector has shown great dynamism with the structural reforms initiated, a great geographical expansion, ... But, the international financial crisis has caught up with the banks with capital foreigners, Citi and Fortis (BCDC) listed on the stock market and having a risk exposure of "subprime". Thus, he will say, "there is the need for the local banks to be very cautious in placing their foreign currency holdings with their foreign correspondents". As far as it is concerned, the $\mathrm{CBC}$ will help the local banks that want it and have their assets protected at the Central Bank of Central Banks, the Bank for International Settlements (BIS).

On the economic level, the crisis is about the real economy, says J.C. Masangu. The mining sector which is the locomotive will be affected, following the decline in capitalization and market values that will affect the raising of funds on stock exchanges and bank loans. Beyond that, there is also the fall or fall in prices of mining products (copper, zinc, ...), the slowdown in the world economy that will affect the demand for base metals such as copper ... Consequence, Initial investment or expansion projects have been postponed, stopped or resized. Social related projects will be very affected. New or existing jobs will be threatened by massive layoffs (technical, economic, etc.). In the informal and artisanal sector, the market for heterogeneity, cassiterite and coltan has become less attractive. Moreover, this crisis will have a macroeconomic impact in the Democratic Republic of Congo, with a growth rate of less than 10\%, the fall in purchasing power following imported inflation, oil revenues will decline. At the monetary level, it will be difficult to maintain the stability of the Congolese Franc. And the revenue in currency will go down. As far as the Democratic Republic of Congo is concerned, there is a consequent energy crisis, as the revenue from hydrocarbon production occupies the first position in the state budget structure: "The price of a barrel of oil is denominated in USD and increased from USD 95 at the end of December 2007 to USD 147 in July 2008, then fell back to USD 66 at the end of 2008. Fluctuations in the price of a barrel have a direct impact on the price at the pump; the transportation of goods and persons; the chemical industry, energy production (electricity), the correlation between the fall of the dollar and the rise in the price of a barrel of oil ". In terms of food, the crisis has led to higher prices for imported cereals (rice, wheat, maize, etc.). In the Democratic Republic of Congo, imports exceed local production, which is affected by evacuation, transportation, distribution or conservation issues. At the level of the international trade sektor. After reaching $114.7 \%$ of GDP in 2008, the overall volume of trade fell to $83.4 \%$ in 2009 , mainly because of the effects of the international financial crisis. Indeed, from one year to another. These exchanges passed from 13.6 billion USD in 2008 to 9.3 billion, USD in 2009 is a decrease of $31.6 \%$ [World Bank Report, 2012, pp. 105-106]. Exports of Democratic Republic of Congo goods registered a 36.4\% decline in their values in 2009 against an increase of $11.7 \%$ in 2008. In fact, they stood at 43.710 million USD in 2008 against 6.869, 8 million in 2009. As for mining products, their exports amounted to US $\$ 4,240.1$ million in 2008 , compared with US $\$ 6,587.7$ million in 2009 , a $36.0 \%$ decline in exports of the main mining products.

\section{Copper [World Bank report, 2010, pp. 118-119]}

Total production of copper, which is considered as the engine of the economy of the Democratic Republic of Congo fell by $7.7 \%$, the share of Gécamines fell by $43.5 \%$ to 13.274 tons in 2009 against 23.475 tons in 2008 . This company is stuck with structural difficulties namely the lack of new investments, the obsolescence of the production tool.

\section{b. Cobalt}

- Cobalt went from US \$3,000 per ton in November 2007, passing through US \$5,000 in the first half of 2008 to less than US \$ 4,000 in November 2008. Regarding the production of cobalt, it registered an increase of $32.5 \%$ in 2009 , amounting to 56,258 tons against 42,461 tons in 2008 . The share of Gecamines is still marginal, representing $0.8 \%$ against $92.2 \%$ returning to its partners. 


\section{c. Zinc}

Available zinc data for Gecamines production alone show an increase in production of $27.0 \%$ from one year to another of 15,465 tonnes to 19,636 tonnes.

As in previous years, this increases in production results from the regular supply of zinc oxide to a partner of this company.

\section{d. The Etain [World Bank report, 2010, pp. 118-119]}

On the side of mining exports, the financial shock is also strongly felt. Tin still mined in Canada is experiencing a drop in its world price. After reaching US \$ 2500 per ton in November 2008, tin is resold in November 2009 below its value at US $\$ 1,700$.

\section{e. Wood}

The production of firewood and charcoal increased by $3.0 \%$ each in the period under review, following the same level of growth a year earlier. This situation is due to the intensive use of household forest products to cope with the recurrent deficit in the supply of electricity.

\section{f. The diamond}

The diamond saw a decrease of $12.8 \%$ in 2009 , amounting to 18,275 thousand carats against 20,947 thousand in 2008 . In addition to the unfavorable international environment, this evolution is explained by the stop of the activities of the Miba. In this country imports of basic foodstuffs claim that, as a result of the financial crisis, imported food products have increased in price. There is a rise in the price of imported cereals (rice, wheat and maize). The table below illustrates the price effect of staple foods that are imported into the Democratic Republic of Congo before and after the financial crisis.

Table 1 - Price effect of imported staple foods in the DRC.

\begin{tabular}{|l|l|l|}
\hline Food products & Pre-crisis price in US \$ & Post-crisis price in US \$ \\
\hline Carton horse mackerel & 30 & 68 \\
\hline Chicken carton & 24 & 48 \\
\hline Rice bag 50kg & 26 & 54 \\
\hline Sugar bag 50kg & 40 & 65 \\
\hline
\end{tabular}

Source: Developed by the author on the basis of the data acquired from Boyi Nkfulibongo,

Mayi Ndombe Mayi University (Mayi Ndombe University) June 17, 2011

\subsection{In the employment sector}

The problem of job creation is one of the permanent and legitimate concerns of the public authorities. Like other African countries, the Democratic Republic of Congo has a national employment policy. The destruction of several production units combined with the massive and precipitous departure of expatriate entrepreneurs in the aftermath of the looting of 1991 and January 1993, which has deteriorated the economic fabric of our country, have not only led to a widespread decline in national production, but have also led many companies to lay off a large part of the working population. The private sector is experiencing a decline in employment as a result of dismissals for economic reasons, while the public administration deplores an increase in the number of agents. The mining sector has been hard hit by the reduction in employment, with an estimated $60 \%$ of the drop in employment in the sector. Thousands of workers are at home as a result of the crisis in the mining sector. The public sector is failing to take over its agents and liberalize the mining sector of state-owned enterprises in order to create jobs for the thousands of Congolese who are unemployed. Unemployment has particularly affected SMEs and comptoirs engaged in the extraction and / or marketing of precious stones and other minerals. The institutions found themselves without takers of their goods. This forced many of them to simply close their doors. This was, for example, a non-exhaustive example.

The cases of companies based in Katanga such as:

- Shedon Miting;

- Zongu Miting;

Anvie Mining[Cartanapis André, 2009, p. 93] .

However, in a country where the unemployment rate was already above $50 \%$ this could only worsen the situation, too. Since the Democratic Republic of Congo has a highly dependent mining economy that is operational in almost every province in the country, the crisis in the mining sector is a crisis with serious consequences for the country's economy. Although the phenomenon first and foremost occurred in Katanga, the first mining region of the country, and where there were already in December 2008 more than 400,000 workers returned to unemployment, as well as North Kivu, South Kivu and in eastern province. This is a phenomenon that continues to recover while the crisis persists, and which should affect all the provinces of the country for the reason under-mentioned, this implies that taken as income producing sector especially in the form of currencies. Many situations of mass dismissal show that unemployment in the Democratic Republic of Congo in the aftermath of the crisis is not only in the mining sector. Even telecommunications operators, 
which are the quasi-monopoly companies in the Democratic Republic of Congo, have been forced to reduce their staff following the crisis. This is also the case in several other local branches of Western multinationals based in the Democratic Republic of Congo where layoffs take place without fanfare. The Democratic Republic of Congo has training structures and employment regulations: the National Employment Office (ONEM), the National Institute of Professional Preparations (INPP) in the Democratic Republic of Congo.

The employment situation is worrying in our country. According to recent studies conducted by the International Labor Office and the Central Bank of Congo, unemployment and self-employment cover a large part of the Congolese population. Currently, when only the formal sector is taken into account, the unemployment rate is estimated at $96 \%$ (Scandalous unemployment rate). In the prosperous years of the Democratic Republic of Congo until the 1982 scientific census, this rate was estimated at $8 \%$. This increase in the unemployment rate can not leave us indifferent. This situation is related to the following main causes:

- destruction and degradation of the production tool;

- the poor state of communication infrastructures;

- the low rate of growth of investments;

- the wars;

- red tape;

- legal uncertainty;

- bad governance;

- Corruption.

Agricultural exports accounted for only $15 \%$ of GDP in 2007, compared with $40 \%$ in 1960 . Once flourishing, with a smaller output now. The agricultural sector in DRC today is totally paralyzed, it knows an asthenia of production of foodstuffs (production or products of first necessities). Exports of cash crops have declined in recent years in subsistence activities despite favorable natural conditions, but agriculture remains the main sector of the economy accounting for $57.9 \%$ of GDP. The main products exported are: coffee, cocoa, rubber and wood. Whereas food crops mainly concern: Cassava, maize, peanuts, rice, vanzou, millet, beans, soya, peas. Already in 2008 agriculture occupied 52\% of the population.

\section{CONCLUSION}

At the end of our study devoted to the analysis of the financial crisis of 2008-2009, we will set out below the results we have achieved. Our study has three chapters, the first chapter gives, a historical overview of economic crises in the world, the second chapter analyzes the root causes of the international financial crisis 2008-2009, the third chapter finally confronts the Congolese economy has the situation of the international financial crisis 2008-2009. The low hypothesis of our study is as follows: We have admitted that the Democratic Republic of Congo may have been contaminated by the international financial crisis of 2008-2009, particularly in the commodity export sector and the import of industrial products. and food. In order to verify the hypothesis described above, we have resorted to methods and techniques of scientific research. Regarding the methods, the deductive and inductive method was used, as for the research techniques, the following techniques were put in contribution, notably the documentary technique and the interview. After our various investigations, the following observations were made:

\section{Crises under capitalism}

Are inevitable because this regime aims to profit, When purchasing power decreases, the consumer buys less, industries are often in trouble and need banks to maintain their business. If the evil persists, the factories close, the unemployment spreads and decreases the consumption, the stock accumulates, the price collapses, the weakest companies disappear, dragging with them the banks too committed. But other companies resist, absorbing even their competitors: the concentration increases. When consumption resumes, commercial and banking industrial activities are experiencing a new boom, businesses are fewer and more powerful than before the crisis. The intervention of the state makes crises less serious, and it is that we have seen during the international financial crisis where the state that it is in the United States, in Europe, shows itself to the author of its power, by financing the banks and large companies that have committed themselves to the "SUBPRIME" credit risk and securitization phenomenon that have seriously spread the financial crisis in the US, in Europe and in African countries including the Democratic Republic of Congo, which did not participate in the furniture credit initiated in the USA, but unfortunately are unjustly hit by the crisis. In the Democratic Republic of Congo the consequences of the international financial crisis of 2008-2009 are felt at the macro-economic level, in fact the decline in economic growth of the main partners of the Democratic Republic of Congo is reflected in the decline in imports of these partners which imports are our exports as well as their direct and portfolio investments. It follows, the accentuation of the slowdown in the economic growth of the Democratic Republic of Congo. At the level of international trade, the overall volume of trade has fallen because of the effects of the international financial crisis. (This trade reached $114.7 \%$ of GDP in 2008, but in 2009 it reached $83.4 \%$ ).

\section{In the mining sector a) Copper}

Considered as the locomotive of the economy of the Democratic Republic of Congo, its production fell by $7.7 \%$, the share produced by Gécamines fell by $43.5 \%$, this company is stuck with structural difficulties namely the lack new investments, the obsolescence of the production tool. 


\section{b) Cobalt}

Its production by Gécamines is very marginal, it represents $0.8 \%$ in 2008 against $92.2 \%$ the share produced by its partners. c) Zinc

As a result of capitalization and market value, the price has fallen globally.

d) Tin

Also knows a drop in its world price. After reaching US \$ 2,500 per ton in November 2008, tin is resold in November 2009 below its value of US \$1,700 in 2009.

e) The Wood

Sells badly, because investors no longer get credit near bankrupt banks in Europe is in the US

\section{f) The Diamond}

Decreased by $12.8 \%$ in 2009 , and sells poorly as a result of the unfavorable international environment and the shutdown of the largest producer in the Democratic Republic of Congo, which is the miba

\section{Imports of basic food products}

As a result of the financial crisis, imported food products have increased in price. There is a rise in the price of imported cereals (rice, wheat and maize). Carton horse mackerel before the crisis costs $\$ 30$ today sells for $\$ 68$, chicken before the crisis costs $\$ 24$ today sells $\$ 48$, rice $(50 \mathrm{~kg})$ 26dollars before the crisis 54 dollars today, sugar 40 dollars before the crisis 65 dollars today.

\section{In the employment sector}

The mining sector has been hard hit by the reduction in employment, to the point where the level of employment decline in the sector is estimated at $60 \%$. Thousands of workers are at home as a result of the crisis in the area. Unemployment has particularly affected SMEs and comptoirs engaged in the extraction and / or marketing of precious stones and other minerals, Minning based in Katanga where many of them have simply closed their doors.

\section{In the agricultural, industrial and service sector. \\ - Agriculture}

Agricultural exports accounted for only $15 \%$ of GDP in 2007-2008, compared with 40\% in 1960. Exports of foodstuffs have declined and in recent years have been reduced to subsistence activities, despite favorable natural conditions in the country, that is to say several billion hectares of arable land and the rainfall of 24 months per year and if it rains south to north is the dry season and vice versa, it must be said that agriculture remains in the Democratic Republic of Congo, the sector of the economy that occupies $80 \%$ of the population, it is therefore important to deal with agriculture.

\section{- Industry}

Formerly important for the Democratic Republic of Congo, this sector contributed only 5.6\% of GDP in 2008, it is currently composed of a few small factories in textiles, food, chemistry and the goods sector. equipment.

The industries have suffered from the crisis in the country.

In fact, manufacturing industries have been cut off from their sources of raw materials supply and their outlets for finished products.

They would only use between 15 and $17 \%$ of their installed productive capacities.

\section{- Service}

In the Democratic Republic of Congo the service sector is dominated by transport and telecommunications, timidly there is trade that attracts investors (Lebanese, Chinese, and others.)

We have not analyzed all the problems posed by the international financial crisis in the Congolese economy, however we have examined the essential, we are aware of the weaknesses that could be noted about this study, any human work being imperfectible.

\section{BIBLIOGRAPHY}

[1].Amesila LIKE A., Analysis of Monetary Instability in the Democratic Republic of Congo; case of the Congolese franc against the US dollar from 1998 to 2003, end-ofcycle work, UNIKIS, 2005-2006, Kisangani.

[2].Banque mondiale, Global Economic Prospects : Commodities at the Crossroads, Washington, 2009.

[3].Bendera Omar, The global economic crisis, its origin and prospects.Available on http://lemaghrebin.com/accueil/index.html

[4].Boulager G., Social Science Research, ed. Universal, Paris, 1975

[5].De Boissieu C., Dictionary of Economics, Ed. PUF, Paris, 2000

[6].Cartanapis André, The financial crisis, its causes, its course, its consequences. What lessons? OFCE Study Day Paris, February 12, 2009

[7].Esico Fatuma, The effects of the financial crisis on economic growth in the DRC. From 2001 to 2010, memory, UNIKIS, 2010-2011, Kisangani

[8].Guy Longueville and François Faure, «Les pays émergents désormais ébranlés par la crise international », BNP Paribas, note de conjoncture, décembre 2008.

[9].MISHKIN F.; Monnaie, banque et marche financier, $8^{\mathrm{eme}}$ éd, nouveaux horizon, paris, 2007 
[10]. NKERE N. ; La crise financière international de 2008-2009 et ses conséquences en RDC, éd, harmattan, France 2009

[11]. Nosakwe P., " L'Afrique subsaharienne et la crise financière mondiale », note EPCDM, Vol 7, Nº10, Déc. 2008Janv. 2009.

[12]. Philippe Hugon, L'Economie de l'Afrique, Paris, Repères (6ème ed.), 2009.

[13]. Pirou J-P., Lexicon of Economics and Social Sciences, 7th ed. The Discovery, collection REPERES, Paris

\section{LA CRISE FINANCIÈRE INTERNATIONALE DE 2008-2009 FACE À L'ÉCONOMIE CONGOLAISE \\ Résumé}

Cet article décrit la crise financière internationale de 2008-2009 face á l'économie congolaise. La crise financière internationale de 2008-2009 a fait naître de graves dangers pour l"économie congolaise en termes de pertes d"emploi et de baisse de qualité de vie. La crise économique et financière est mondiale et elle touche aussi les pays les plus vulnérables comme les pays africains. Cela est d"autant vrai car, il est généralement admis que la situation économique a une influence sur la situation sociale. En effet, bien que la crise ait été déclenchée par des événements qui se sont produits sur le marché immobilier aux États-Unis, elle s'est propagée à toutes les régions du monde et les conséquences en sont désastreuses pour le commerce, la croissance et les investissements mondiaux. En République Démocratique du Congo, la crise financière mondiale qui avance rapidement, emporte entreprises, mines, emplois, revenus et moyens d"existence. Le temps presse et l"action décisive ne peut plus attendre.

Mots-clés: crise financière; crise financière internationale, Banque centrale du Congo Code JEL : E5, E32, E44, F32 